\title{
Virus Induced Gene Silencing of prolyl-4-hydroxylase Induce alteration in Plant Growth
}

\author{
Faruk Berat Akcesme \\ International University of Sarajevo,Faculty of Engineering and Natural Sciences \\ Hrasnicka Cesta 15, 71000 Sarajevo,Bosnia and Herzegovina \\ fakcesme@ius.edu.ba
}

\begin{abstract}
Prolyl 4-hydroxylases (P4Hs) belong to the family of 2-oxoglutarate-dependent dioxygenases and catalyze the formation of 4-hydroxyproline, requiring 2-oxoglutarate and $\mathrm{O}_{2}$ as co-substrates and $\mathrm{Fe}^{2+}$ as a co-factor. Nine putative P4Hs have been identified up to now in the tomato genome. A reverse genetics approach, Virus-Induced Gene Silencing, was used to silence two P4Hs, P4H3 and P4H8. Transient silencing of $\mathrm{P} 4 \mathrm{H} 3$ and $\mathrm{P} 4 \mathrm{H} 8$ altered tomato plant growth. P4H3- and P4H8-VIGS plants had shorter stems, reduced fresh weight and smaller leaves. The effect of VIGS application in different plant organs such as root, shoot, and root fresh weight, shoot fresh weight, leaves area were analyzed. Linear correlation was measured by calculating the Pearson correlation coefficiency in order to see if there are correlations between these variables. These results indicate that P4H3 and P4H8 play a significant role in tomato plant growth and VIGS is a useful tool to study the function of tomato gene families such as P4Hs in growth and development, and elucidate, in the long run, the physiological significance of substrate-proteins such as hydroxyproline-rich glycoproteins.
\end{abstract}

Key word: prolyl-4-hydroxylase, plant growth, correlation, regression

\section{INTRODUCTION}

Prolyl 4-hyroxylases (P4Hs) catalyze the formation of 4-hydroxyproline and belong to the family of 2oxoglutarate and non- heme-Fe (II)-dependent deoxygenizes (2-ODDs). P4Hs require $\mathrm{Fe}^{+2}$ as a cofactor and $\mathrm{O} 2$ and 2-oxoglutarete as cosubstrate for their catalytic activity (Figure. 1.1) [1]. P4Hs have been found in vertebrate, invertebrate and plant organisms. In mammalian cells, 4-hydroxyproline is abundant in collagen and collagen-like proteins, while in plants there is a superfamily of cell wall glycoproteins, rich in hydroxyproline, collectively called hydroxyproline-rich glycoproteins (HRGPs). $\mathrm{P} 4 \mathrm{Hs}$ have been cloned and characterized from 
Caenorhabditis elegans [2] and Drosophila melanogaster [3].

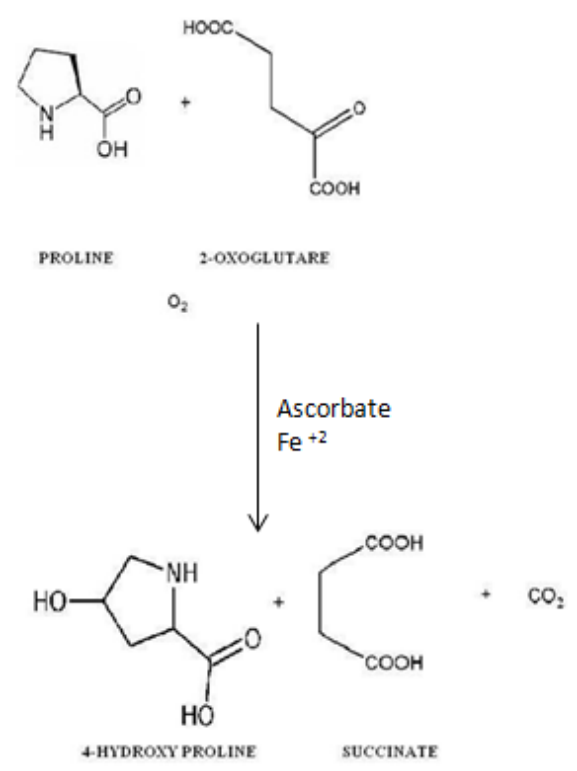

Figure 1 Hydroxylation of prolyl residues to 4-hydroxyproline (E.Jespord, 2005)

Till today, a function similar to HIF-P4Hs has not been identified in plants. Nevertheless, the proteome of a plant cell wall is abundant in hydroxyproline-rich glycoproteins (HRGPs), a superfamily of glycoproteins that play an essential role in almost all aspects of plant growth and development.

Prolyl hydroxylation is significant for plant growth and to this direction may affect plant yield, since leaf growth and the productivity of plant are related. Moreover, ripening excised tomato pericarp discs and carnation petals treated with $\mathrm{P} 4 \mathrm{H}$ inhibitors had lower ethylene production, which affected the evolution of ripening and senescence processes respectively (Fragkostefanakis et al., 2011 unpublished data; Vlad et al., 2010). Collectively, these results emphasize the importance of $\mathrm{P} 4 \mathrm{Hs}$ in plant developmental processes. This study aimed to analyze the effect of $\mathrm{P} 4 \mathrm{H} 3$ and P4H8 on tomato plant growth and its organs and their organs growth correlations due to silencing.

\section{METHODS}

Today, the vast amount of information emerging from the sequencing of genomes from different organisms strengthens the necessity for the development of more rapid and reliable reverse genetics techniques. Virus- induced gene silencing (VIGS) is a reverse genetics tool used for the analysis of gene functions. VIGS technology uses viral vectors which carry a fragment from a gene of interest in order to produce dsRNA which eventually triggers RNA-mediated gene silencing [4]. Since gene expression is suppressed at the posttranscriptional level, VIGS, among other RNAi techniques, belongs to the post-transcriptional gene silencing (PTGS) methods such as quelling in fungi [5] and RNA interference in animals [6]. VIGS allows the identification of a loss-of-function phenotype for a specific gene within a single generation because the gene of interest is directly targeted in VIGS, in contrast with technologies such as chemical mutagenesis, transposons or T-DNA insertions [7]. In general, the phenotype due to VIGS-silencing might be developed from 10 to 15 days after the delivery of the virus vector into the plant cells ([8]. VIGS has been used for the functional characterization of genes in different plant organs such as roots [9], leaves [10], tubers, flowers [11] and tomato fruits [12]. The relative expression of $\mathrm{P} 4 \mathrm{H} 3$ and $\mathrm{P} 4 \mathrm{H} 8$ was determined in control and VIGS plants by real-time ime PCR. Total RNA was isolated from the pooled tissues of 19 plants and subjected to RNase-free DNase treatment. Real-time PCR was performed using SYBR Green on the ABI PRISM 5700 sequence-detection system. Morphological analysis was performed for P4H3-, P4H8-VIGS and control tomato plants. Nineteen plants were used from each treatment. Six weeks after the infection, the plants were photographed, and then their shoot, root length, fresh weights and leaf areas were determined individually. The area of the 3rd, 4th, 5th and 6th leaf of P4H3-, P4H8-VIGS and control plants was measured using the online leaf area assessment tool (OLA) (13).

\section{Statistical Analyzes}

The experimental design was a completely randomized. Data were subjected to T-test analysis for paired samples with significant difference at $\mathrm{p}<0.05$, using the statistical software SPSS Statistics for Windows. Furthermore the effect of VIGS application in different plant organs such as root, shoot, root fresh weight, shoot fresh weight, leaves area were analyzed. Linear correlation was measured by calculating the Pearson correlation coefficiency in order to see if there are any correlations between these 
variables using Statistical software SPSS Statistics for Windows.

\section{RESULT}

The expression profiles of $\mathrm{P} 4 \mathrm{H} 3$ and $\mathrm{P} 4 \mathrm{H} 8$ were monitored in VIGS- treated and control plants, six weeks after virus infection by quantitative real-time PCR. The expression of each gene is presented as relative to the expression in the control plants. VIGSSilencing resulted in partial suppression of expression of $\mathrm{P} 4 \mathrm{H} 3$ and $\mathrm{P} 4 \mathrm{H} 8$ by $59 \%$ and $64 \%$, respectively, compared to the expression in the control plants in several biological replicates.

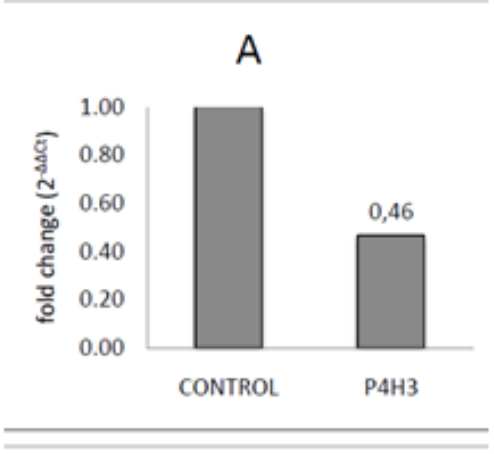

\section{B}

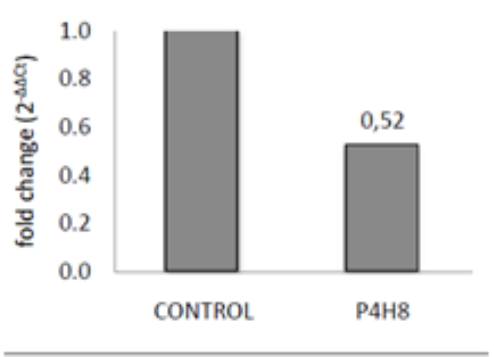

Figure 2 relative expressions of $\mathrm{P} 4 \mathrm{H3}$ and $\mathrm{P} 4 \mathrm{H8}$ in control VIGS-treated plants. Relative fold changes were calculated based on the comparative $\mathrm{Ct}$ method, using actin as an internal standard. The $\mathrm{Ct}$ value for each gene was normalized to the $\mathrm{Ct}$ value for actin and was calculated relative to a calibrator (control) using the formula $2^{-\Delta \Delta C \mathrm{Ct}}$. Vertical bars are the average of three replications.

The shoots were shorter in VIGS-treated plants of both genes $p>0,05 \mathrm{P}=2,36 \mathrm{E}-07$ (Fig3). The average shoot length of P4H3- and P4H8-VIGS treated tomato plants was 13.4 and $16.5 \mathrm{~cm}$, respectively while the shoot of control plants was $19 \mathrm{~cm}$ long (Fig. 3.14). On the other hand, no significant differences were observed in the root length of the control and VIGS-treated plants. P4H3- and P4H8-VIGS treated plants had shorter stems but no effect on root length. The VIGS-P4H3 and P4H8 plants $3^{\text {th }}, 4^{\text {th }}$ and $5^{\text {th }}$ leaves are smaller than the control plants while $6^{\text {th }}$ leaves are not different in size.

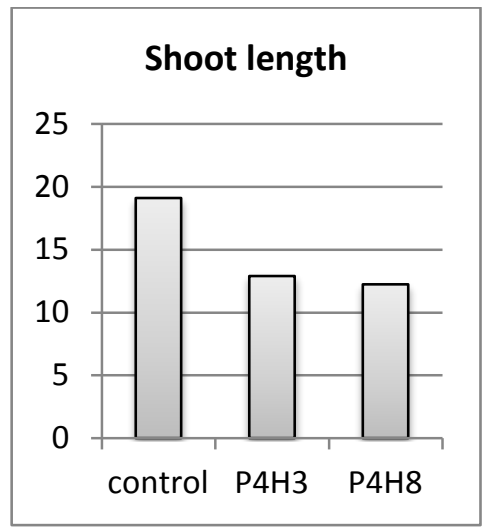

Figure 3There are significant differences on shoot lengths between control and P4H's group. $p>0,05 P=2,36 E-07$

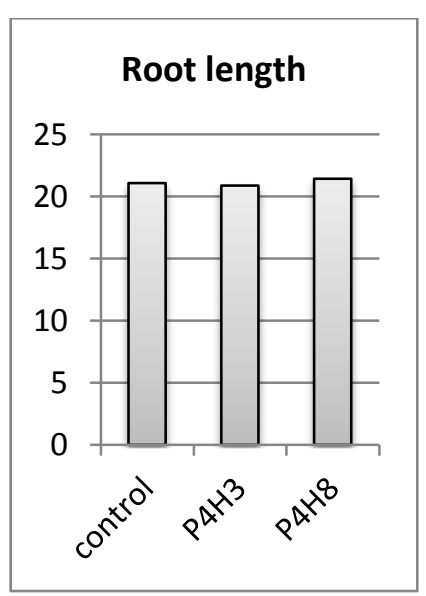

Figure 4There are no significant differences on root length between control and P4H's group. $p>0,05, P=, 91$

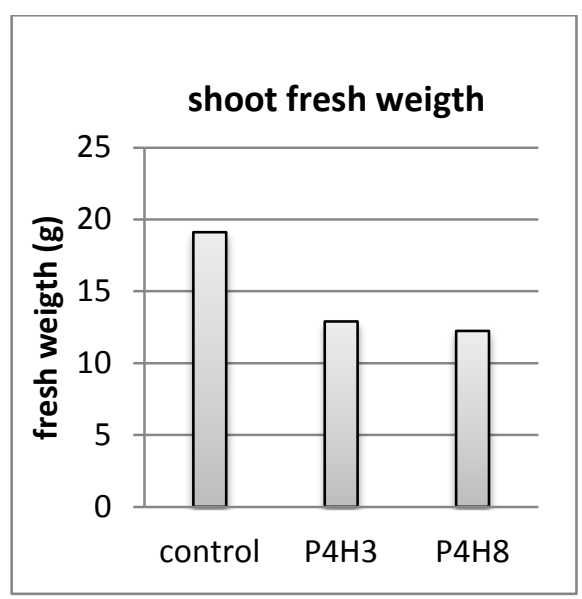

Figure 5There is significant differences on shoot fresh weight between control and P4H's groups. $P=1,55 E-05, p>0.05$ 


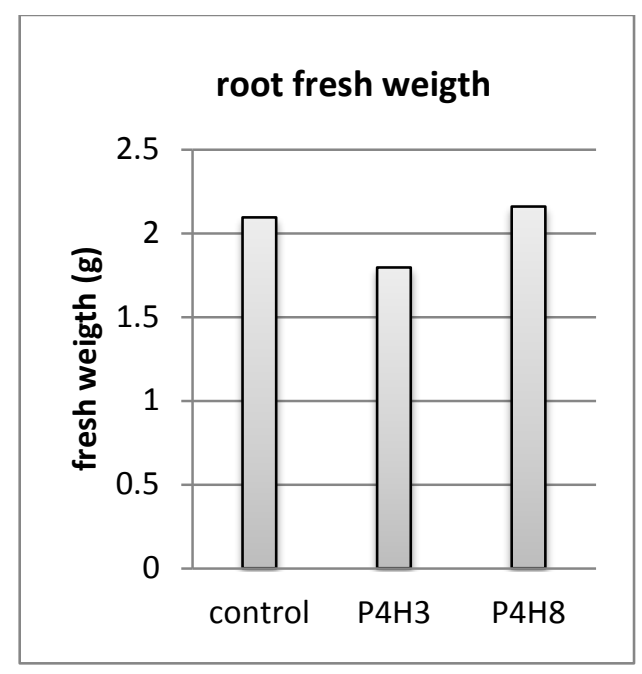

Figure 6There are no significant differences on root fresh weights between control and $\mathrm{P} 4 \mathrm{H}$ 's groups. $\mathrm{P}=0,123, \mathrm{p}>0.05$

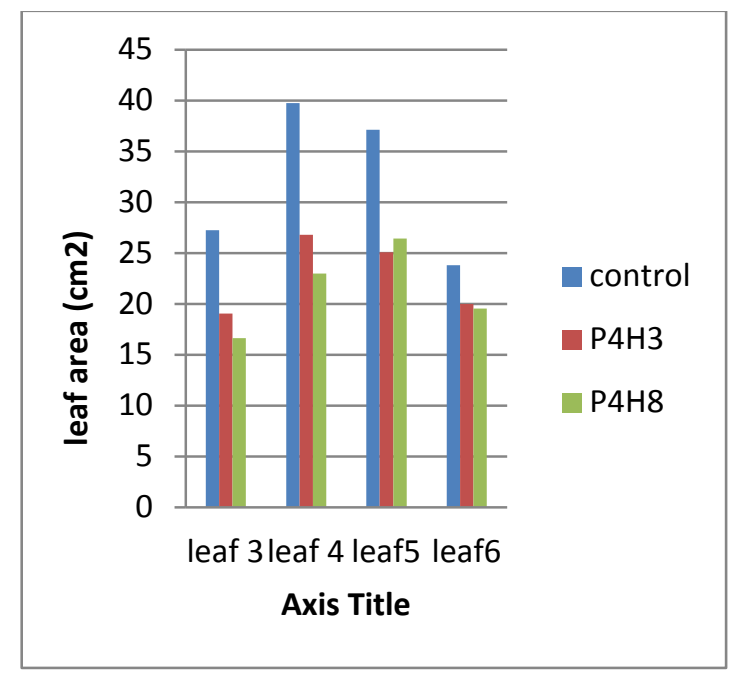

Figure 7 There is significant differences on $3^{\text {th }}, 4^{\text {th }}, 5^{\text {th }}$ but no differences in leaf $6(\mathrm{P}=1,96 \mathrm{E}-08,2,09 \mathrm{E}-08,0,000214,0,217577$ respectively at $\mathrm{p}>0.05$ ).

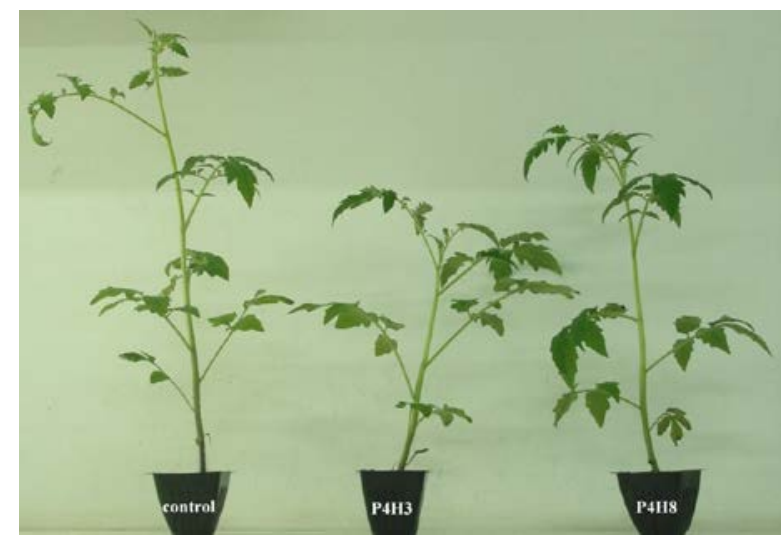

Figure 8 Representative six-week-old control-, P4H3 and P4H8 VIGS-treated plants.
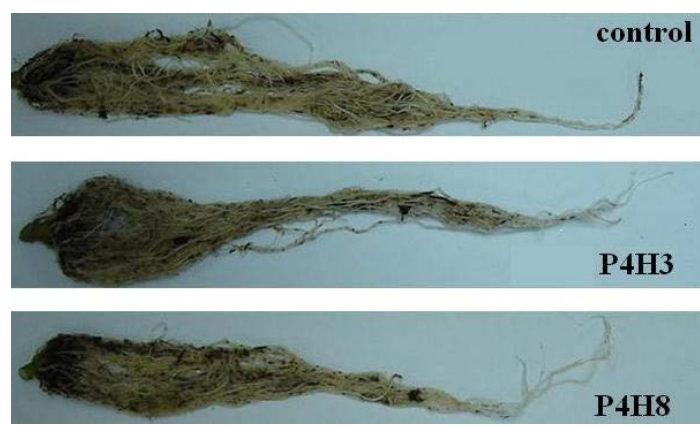

Figure 9 Root length of six-week-old control P4H3-, and P4H8-VIGS.

The area of the 3rd, 4th, 5th and 6th leaf of the P4H3and P4H8-VIGS treated plants was determined and compared to the respective leaf areas of control plants. The 4th, 5th and 6th leaves of both P4H3- and P4H8VIGS plants had a significantly smaller area than the leaves of the control plants. In particular, the area of the 3th, 4th, 5th and leaves of the P4H3 plants was $28 \%, 27 \%$ and $23 \%$ smaller than the control plants. On the other hand, while the and 6th leaf of the $\mathrm{P} 4 \mathrm{H} 3$ and P4H8-VIGS plants were similar to the control plants, the 4th and 5th leaves were $23 \%$ and $17 \%$ smaller, respectively in P4H8-VIGS.

Correlation between shoot length, root length, stem fresh weight, root weight and all tree leaves were analyses and the results indicated in the following table. 


\begin{tabular}{|c|c|c|c|c|c|c|c|c|}
\hline \multicolumn{9}{|c|}{ Corralations in Control, $\mathrm{P} 4 \mathrm{H} 3, \mathrm{P} 4 \mathrm{H} 8$} \\
\hline $\begin{array}{l}\text { Organ } \\
\text { s of } \\
\text { plants }\end{array}$ & $\begin{array}{l}\text { Shoot } \\
\text { lenght }\end{array}$ & $\begin{array}{l}\text { Root } \\
\text { lenght }\end{array}$ & $\begin{array}{l}\text { Shoot } \\
\text { fresh } \\
\text { weight }\end{array}$ & $\begin{array}{l}\text { Root } \\
\text { fresh } \\
\text { weight }\end{array}$ & Leaf 3 & Leaf 4 & Leaf 5 & Leaf 6 \\
\hline \multirow[t]{8}{*}{$\begin{array}{l}\text { Shoot } \\
\text { lenght }\end{array}$} & $\begin{array}{l}1 \\
1 \\
1\end{array}$ & $\begin{array}{l}- \\
0,529 \\
-\end{array}$ & $\begin{array}{l}- \\
- \\
-\end{array}$ & $\begin{array}{l}0,463 \\
0,468 \\
-\end{array}$ & $\begin{array}{l}- \\
- \\
0,515\end{array}$ & $\begin{array}{l}- \\
0,553 \\
-\end{array}$ & $\begin{array}{l}- \\
0,457 \\
-\end{array}$ & $\begin{array}{l}- \\
0,615^{*}\end{array}$ \\
\hline & $\begin{array}{l}\text { Root } \\
\text { lenght }\end{array}$ & $\begin{array}{l}1 \\
1 \\
1\end{array}$ & $\begin{array}{l}- \\
- \\
-\end{array}$ & $\begin{array}{l}- \\
- \\
-\end{array}$ & $\begin{array}{l}- \\
- \\
-\end{array}$ & & $\begin{array}{l}0,486 \\
- \\
-\end{array}$ & $\begin{array}{l}- \\
- \\
-\end{array}$ \\
\hline & & $\begin{array}{l}\text { Shoot } \\
\text { fresh } \\
\text { weight }\end{array}$ & $\begin{array}{l}1 \\
1 \\
1\end{array}$ & $\begin{array}{l}- \\
0.820^{*} \\
-\end{array}$ & $\begin{array}{l}- \\
- \\
-\end{array}$ & $\begin{array}{l}0,731^{*} \\
-\end{array}$ & $\begin{array}{l}- \\
0,597 * \\
-\end{array}$ & $\begin{array}{l}- \\
0,579 * \\
-\end{array}$ \\
\hline & & & $\begin{array}{l}\text { Root } \\
\text { fresh } \\
\text { weight }\end{array}$ & $\begin{array}{l}1 \\
1 \\
1\end{array}$ & $\begin{array}{l}- \\
- \\
-\end{array}$ & $\begin{array}{l}0,690^{*} \\
-\end{array}$ & $\begin{array}{l}0,753^{*} \\
0,558 \\
-\end{array}$ & $\begin{array}{l}- \\
0,468 \\
-\end{array}$ \\
\hline & & & & Leaf 3 & $\begin{array}{l}1 \\
1 \\
1\end{array}$ & $\begin{array}{l}0,522 \\
0,595^{*} \\
-\end{array}$ & $\begin{array}{l}- \\
- \\
-\end{array}$ & $\begin{array}{l}- \\
0,543 \\
-\end{array}$ \\
\hline & & & & & Leaf 4 & $\begin{array}{l}1 \\
1 \\
1\end{array}$ & $\begin{array}{l}- \\
0,651 \\
-\end{array}$ & $\begin{array}{l}- \\
0,579 * \\
-\end{array}$ \\
\hline & & & & & & Leaf 5 & $\begin{array}{l}1 \\
1 \\
1\end{array}$ & $\begin{array}{l}0,563 \\
0,746^{*} \\
0,623^{*}\end{array}$ \\
\hline & & & & & & & Leaf 6 & $\begin{array}{l}1 \\
1 \\
1\end{array}$ \\
\hline
\end{tabular}

Table 1The indicated numbers represent the correlation between different organs at $p<0.05$. (*) represents the corralation at $\mathbf{p}<0.01$. Each row in each cell represent correlation within Control,P4H3, P4H8, respectively.

\section{DISCUSSION AND CONCLUSION}

Prolyl hydroxylate is important for plant growth and development. Leaf size is of particular interest for tomato crop, since along with stem density and number of leaves per stem influence light interception and subsequently photosynthesis and tomato yield. To this direction, we investigated the role of two $\mathrm{P} 4 \mathrm{Hs}$, $\mathrm{P} 4 \mathrm{H} 3$ and $\mathrm{P} 4 \mathrm{H} 8$ using a reverse genetics approach such as VIGS. P4H3- and P4H8-VIGS treated plants had shorter stems but no effect on root length. The VIGS-P4H3 and P4H8 plants $3^{\text {th }}$, 4th and $5^{\text {th }}$ leaves are smaller than the control plants while $6^{\text {th }}$ leaves are not different in size. In all groups there are different correlations between leaves as expected, especially in VIGS-P4H3 there is correlations between leaves in all VIGS plants except between leaf 3 and leaf 5 . Although in control groups, in most of the organs there is no correlations that could be biologically significant related to plant growth, there is significant correlation between different organs in $\mathrm{P} 4 \mathrm{H} 3$ silenced plants. There is also high correlation between shoot weight and all leaves and root weight and all leaves in VIGS$\mathrm{P} 4 \mathrm{H}$ plants while no correlations seen in the control group. This result shows us that the viral replication occurred in every organs on plants and VIGS was successfully applied. Although VIGS-P4H8 plants have very similar morphological changes with $\mathrm{P} 4 \mathrm{H} 3$, interestingly, their organs size changes are not correlated to each other as it is in the P4H3. To figure our the reason should be analyzed in the further studies. All these analyze could be concluded that $\mathrm{P} 4 \mathrm{H}$ has important role in plant organs growth and these growths are correlated to each other.

\section{REFERENCES}

1. Myllylä R, Tuderman L and Kivirikko K.I. (1977) Mechanism of the prolyl 4-hydroxylase reaction. 2. Kinetic analysis of the reaction sequence. Eur $J$ Biochem 80: 349-357.

2. Showalter A.M. (1993) Structure and function of plant cell wall proteins. Plant Cell, 5:9-23.

3. Annunen P, Koivunen P, and Kivirikko K.I. (1999) Cloning of the alpha subunit of prolyl 4hydroxylase from Drosophila and expression and characterization of the corresponding enzyme tetramer with some unique properties. Journal of Biological Chemistry 274, 6790-6796.
4. Unver $\mathrm{T}$ and Budak H (2009). Conserved microRNAs and their targets in model grass species Brachypodium distachyon. Planta: 230:659-69

5. Romano N and Macino G. (1992) Quelling: transient inactivation of gene expression in Neurospora crassa by transformation with homologous sequences. Molecular Microbiology 6, 3343-3353.

6. Fire A, Xu S, Montgomery M.K, Kostas S.A, Driver S.E, and Mello C.C. (1998) Potent and specific genetic interference by double-stranded 
RNA in Caenorhabditis elegans. Nature, 391:806811.

7. Baulcombe D.C, Jones L. and Ratcliff F. (2001) RNA-directed transcriptional gene silencing in plants can be inherited independently of the RNA trigger and requires Met1 for maintenance. Current Biology 11:747-757.

8. Lu R, Malcuit I, Moffett P, Ruiz M.T, Peart J, Wu A.J, Rathjen J.P, Bendahmane A, Day L. and Baulcombe D.C. (2003) High throughput virusinduced gene silencing implicates heat shock protein 90 in plant disease resistance. EMBO J. 22: 5690-5699.

9. Ryu C.M, Anand A, Kang L, Mysore K.S. (2004) Agrodrench: a novel and effective agroinoculation method for virus-induced gene silencing in roots and diverse Solanaceous species. Plant Journal 40, 322-331.
10. Liu Y, Schiff M, Marathe R and Dinesh-Kumar S.P. (2002b) Tobacco Rar1, EDS1 and NPR1/NIM1 like genes are required for Nmediated resistance to tobacco mosaic virus. Plant J. 30: 415-429.

11. Chen J-C, Jiang C-Z, Gookin T, Hunter D, Clark D, Reid M. (2004) Chalcone synthase as a receptor in virus-induced gene silencing studies of flower senescence. Plant Mol Biol. 55: 521-530.

12. Fu D.Q, Zhu B.Z, Zhu H.L, Jiang W.B, Luo Y.B. (2005) Virus-induced gene silencing in tomato fruit. Plant Journal 43, 299-308.

13. Can M, Gursoy O.I Akcesme F.B, Akcesme B (2012) Leaf area assessment by image analysis Southeast Europe Journal Soft Computing volume 1,No2,9-10. 